http://www.jfas.info

\title{
SYSTEM APPROACH TO DEVELOPMENT OF PROFESSIONAL COMPETENCE OF STUDENTS AND MANAGERS IN PROJECT ACTIVITY USING ACMEOLOGICAL TECHNOLOGIES
}

\author{
O. D. Polezhaeva*, A. S. Galchenko, V. N. Sofina, N. N. Obozov, M. P. Gabova
}

North-Western Institute of Management of the Russian Presidential Academy of National Economy and Public Administration, Saint-Petersburg, Russia

Published online: 08 August 2017

\begin{abstract}
This article examines the issue of developing the professional competence of students and managers with the use of acme logical technologies. The influence of acme logical technologies, which are used in professional-oriented creative projects, is regarded, considering its effect on the development of professional competence.
\end{abstract}

Keywords: acmeological technologies, professional competence

\section{INTRODUCTION}

The study of influence of various acmeological technologies on the development of professional competence in the system of continuous education is a significant and urgent issue directly associated with the quality of education.

Acmeological technologies represent a system orderly-functioning complex of interactive educatory technologies (informational, training, play-simulating etc.) ensuring the predicted result of professional competence development in the system of academic-researchprofessional integration. [2]

The objective of the paper was to study the influence of acmeological technologies on the development of professional competence of students and managers participating in the professional-oriented creative projects including the system of advanced training for managers.

Author Correspondence, e-mail: polezhaevaolga@yandex.ru

doi: http://dx.doi.org/10.4314/jfas.v9i2s.851 
The study involved 76 Master's students and 68 managers of different specialties taking part in the development of various research, creative and professional projects.

For the development of professional competence the acmeological technologies were used in the project activity which included the automated system of comprehensive acmeological diagnostics (ASCAD) and different training technologies.

These technologies were used to monitor the development of professional competence of students and managers and teach the efficient models of project activity.

The primary objective of using acmeological technologies in the educational process was to develop main components of professional competence. The creative function was implemented in the process of fulfillment of a system of tasks teaching the methods of selfanalysis, project team building and management.

One of the tools to develop professional competence was the automated system of comprehensive acmeological diagnostics designed using modular approach. In order to teach the methods of project team building the "Behaviour Patterns" module was used including the methods for analysis of the personality type (V.M. Tanayev), personality forms (S. Dellinger) and thinking style (A.A. Alekseyev and L.A. Gromova). Alongside with ASCAD a special system of tasks on the project team building was used which was single for students and managers. [4]

The system of tasks was focused on the development of differential-psychological, sociopsychological, auto-psychological, acmeological and managerial competence of the project team participants.

Acmeological training and play-simulating were used to teach the efficient models of interpersonal interaction in teams.

The acmeological training represents a complex of methods and techniques of interpersonal interaction and is a means to develop all components of professional competence. It is a broad system of special psychological effects and practices which are focused on the overall process of generation, development and/or improvement of professional and personal behaviour of students and managers. [2]

The acmeological training is behaviour-oriented which ensures not only knowledge extension but also shaping of certain behaviour patterns in project teams, and helps to expand behaviour tactics and methodological tools.

The advantage of acmeological training in contrast with many other methods is its applied nature. It teaches students and managers an efficient settlement of practical tasks emerging in the project activity. 
The primary focus of the training is the development of professional competence of the training participants, and "shaping of efficient patterns of work of the project teams with due account for a number of factors (personal and psychological characteristics and level of professional competence maturity etc.)" [5].

While preparing the acmeological training its goals and objectives shall always be clearly stated: particularly what kind of professional behaviour of students and managers shall be shaped, developed and improved. In this case the training has a sustainable intellectual and emotional impact on each of the participants. [3]

The acmeological practice-oriented trainings used to teach the project teams in the system of academic and professional integration involving the elements of play-simulating are listed below.

"Team Building and Management" training. The training is designed to develop the following skills: to efficiently manage the project team; "actively listen" and hold a dialogue; assign roles in a team. It is instrumental in the development of auto-psychological, sociopsychological and managerial competence.

"Negotiation Skills" training. The training helps to develop such skills and abilities as: to listen efficiently and hold a dialogue observing the behaviour of others and analyzing it; establish sustained positive contact and understand other people; stand one's ground. The training allows developing the ability to successfully resolve conflict situations emerging in the process of communication. The training is focused on the development of differentialpsychological and socio-psychological competence.

"Time Management" training. The training helps to develop the following skills: recognize one's strong and weak points in the area of "time management;" range current tasks with respect to their importance and urgency. In the course of the training the participants obtain specific tools for efficient time scheduling, learn to set a goal properly and make a stepwise plan to achieve it. The training is designed to develop acmeological competence.

"Development of Non-Financial Incentive Scheme" training. The training helps to develop such skills as: to build a team using strong points of each of its members, generate common interests of the team which are based not on the financial interest but on commitment to resolving project tasks; create the atmosphere of trust within the team. The training is focused on the development of differential-psychological and socio-psychological competence.

"Situational Management" training. The training generates the ability to evaluate the managerial situation at hand more precisely; clearly troubleshoot areas of concern and itemize the tasks to be assigned for the project team. The training participants obtain the skills to 
undertake efficient measures to enhance the performance of the team work; ability to choose the managerial style suited for a certain team member; ability to identify the level of readiness of the team members to perform the project task. The training is designed to develop managerial competence.

"Innovative Thinking" training. The training is designed to develop the abilities to analyze the project task, motivate the training participants to resolve it during the specified period and state the expected result. It develops the ability to analyze and take into account the sub-tasks to be resolved including potential risks and difficulties in the process of implementation thereof. The ability to think over the alternative possibilities of resolving tasks with minimum risks and expenses and maximum useful effect is generated. The training is designed to develop all professional competences.

"Effective Managerial Decisions" training. The training is designed to develop such skills as: comprehension of the decision-making process as a managerial function required to take decisions in irregular situations. The training enables to master the "brainstorm" technology, develop the ability to make an action plan, generate understanding of the performance control and feedback. The training is designed to develop managerial competence.

On the next stage the acmeological monitoring of development of the professional competence of Master'sstudents and managers was conducted. The work tool for the overall study was the automated system of comprehensive acmeological diagnostics including the package of methods for the study of a personal and professional development.

The analysis of results of a monitoring of professional competence of the Master's students and managers before and after participation in professional-oriented creative projects using acmeological technologies is presented in Fig. 1 and Fig. 2. 


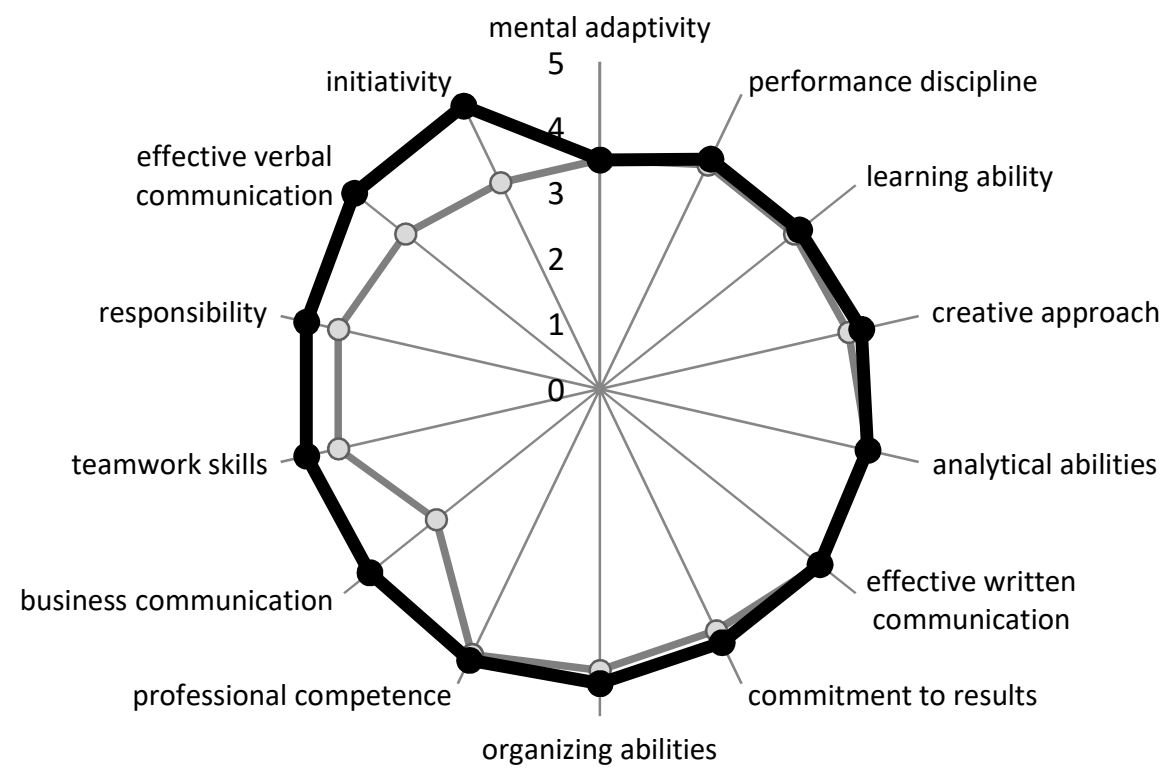

- - (M)Managers before participation in projects

$\longrightarrow$ (MA)Managers after participation in projects

Fig.1. Monitoring of development of the professional competence of managers

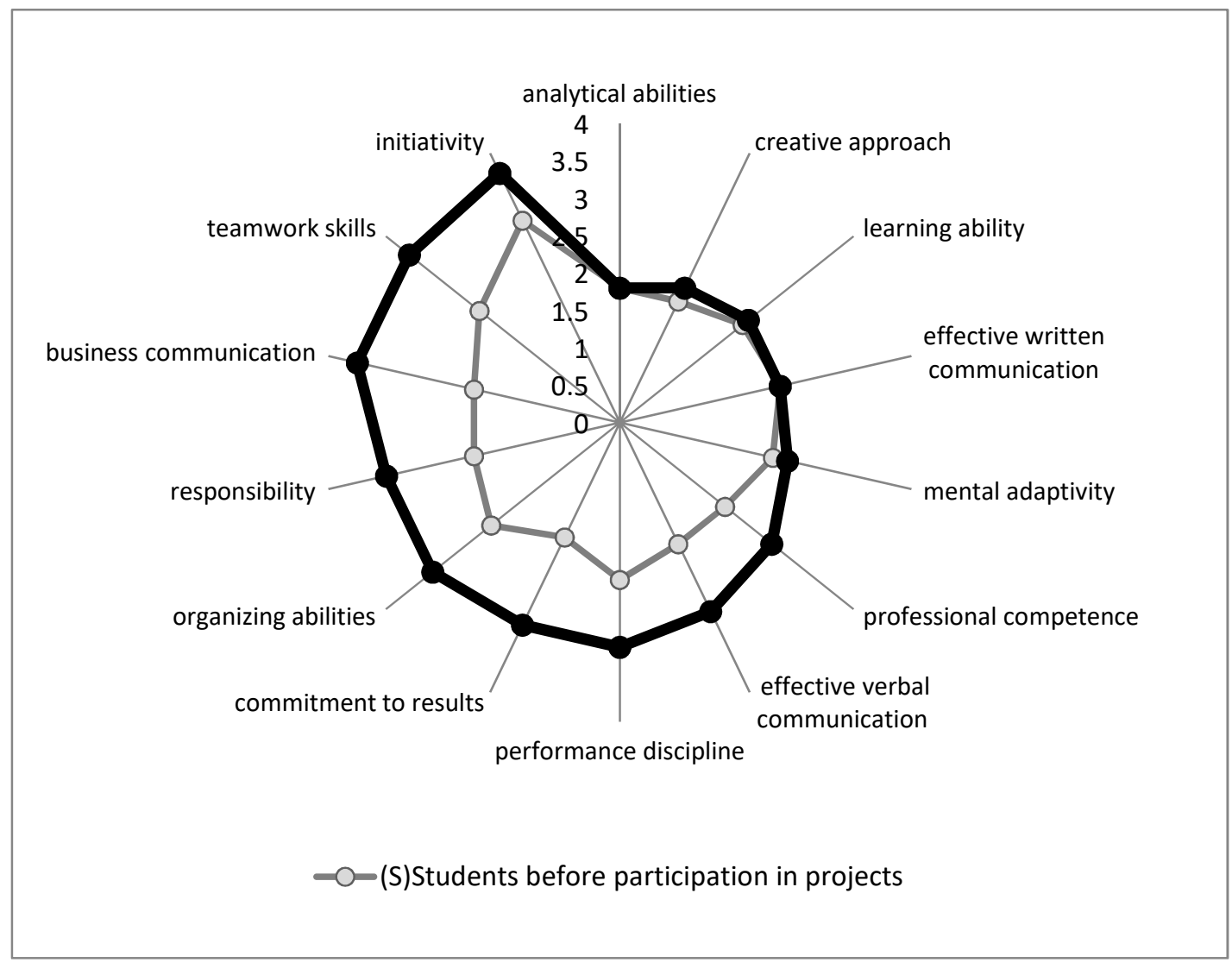

Fig.2. Monitoring of development of the professional competence of students. 
Significant differences with respect to the Student's t-test on the level of $\alpha=0.01$ in the group of managers under study were observed in the following parameters: responsibility $(\mathrm{M}-4.1$; MA - 4.6), business communication ( $\mathrm{M}$ - 3.2; $\mathrm{MA}-4.5)$, initiativity ( $\mathrm{M}$ - 3.5; MA - 4.8), effective verbal communication ( $\mathrm{M}$ - 3.8; MA - 4.8), teamwork skills ( $\mathrm{M}$ - 4.1; MA - 4.6). The specified competences approached the maximum (fifth) level of development.

Positive dynamics of development of professional competences and significant differences with respect to the Student's t-test on the level of $\alpha=0.01$ in the group of Master's students under study were observed in the following parameters: responsibility $(\mathrm{S}-2$; $\mathrm{SA}-3.2)$, commitment to results $(\mathrm{S}-1.7$; $\mathrm{SA}-3)$, teamwork skills $(\mathrm{S}-2.4$; $\mathrm{SA}-3.6)$, business communication ( $\mathrm{S}-2$; $\mathrm{SA}-3.6)$, effective verbal communication $(\mathrm{S}-1.8$; $\mathrm{SA}-2.8)$, initiativity $(\mathrm{S}-3 ; \mathrm{SA}-3.7)$, performance discipline $(\mathrm{S}-2.1 ; \mathrm{SA}-3)$, organizing abilities $(\mathrm{S}-$ $2.2 ; \mathrm{SA}-3.2)$.

Students exceeded the third level of development in such competences as: responsibility, commitment to results, teamwork skills, business communication, initiativity, performance discipline and organizing abilities. Managers developed the same competences at a higher level.

The research results showed that combination of practical-oriented creative project activity and acmeological training technologies had a positive impact on the development of differential-psychological, socio-psychological, auto-psychological, acmeological and managerial competence, particularly on such competences as: responsibility, teamwork skills, effective verbal communication, commitment to results, initiativity and creative approach.

Combination of practical-oriented creative project activity and acmeological training had a positive impact and was a means for development of primary components of professional competence which can be efficiently used in the system of academic-research-professional integration.

ASCAD application as an interactive acmeological technology in resolving primary tasks of building and developing project teams provided a possibility to approach the development of professional competence of students and managers at a higher level in terms of quality and teach them the methods of work and management of the project team.

The next stage was the study of managerial skills of managers. The study of managerial skills is of great significance for improvement of professional activity of managers. From the perspective of the acmeological approach the effective middle managers having different length of management service (under 3 and over 10 years) were studied. Sample group involved 68 persons. The research tool was the automated system of comprehensive 
acmeological diagnostics containing the package of methods for analysis of managerial activity such as: Cycle of Managerial Skills by C.L. Wilson, managerial abilities, leadership style, personality orientation of a manger and other [1]

The methods of C.L. Wilson "Cycle of Managerial Skills" enables to obtain information about the work of a manager not only from him/herself but also from the colleagues, subordinates and heads, which makes it possible to compare the manager's self-assessment and assessments of his/her professional environment. Comparison of the answers of a manger and other specialists enables to reveal strong and weak points in the manager's activity [2].

C.L. Wilson specifies six successive phases in a manager's activity, which comprise a cycle of the management functions.

Phase I consists of establishing a goal the manager fulfills; without setting a goal it is impossible to understand which way to move and what results shall be obtained. Setting a goal is also important for subordinates. Without clear specific goals their motivation will be low.

Phase II - planning how to achieve the goal; phase III - specific steps to put the plan into action. For that the middle manager shall instruct the subordinates on what and how they should do and howtheycan help the team to implement the plan by way of providing with the required material resources, tools, time, work conditions, training etc.

Phase IV is a very important stage and consists in obtaining a feedback. In the course of the task fulfillment the manager shall follow the progress of work and constantly inform the team on the stage of task fulfillment they achieved and how successful they are. In case no progress is observed the manager should make adjustments in the work process by means of tightened control (phase V) up to changing the plans, resources and even goals. Phase VI encouragement and reward of subordinates upon achievement of the goals set when the work is fulfilled.

Each of the six phases involves tasks to be fulfilled in order to implement a certain function. Success of tasks implementation is conditioned by the abilities, knowledge and skills of a manager.

The research was conducted using the automated system of comprehensive acmeological diagnostics which enabled to improve the quality and speed of processing of results $[2,3]$.

The methods include analysis of the following professional skills of managers: explanation of goals and objectives, interrelations with subordinates, thorough planning of the work process, competence of a manager, provision with work conditions, feedback, time control, detail control, goal motivation, delegation of authority, incentive for a good job, orientation to 
people, team building, concern about professional growth of subordinates, trust of subordinates, involvement in work, professional competence of subordinates, group cohesion, favourable conditions for rank advancement, tension level, attitude to people, climate, and performance.

Middle managers with the length of management service under three, five and over ten years took part in the research. As a result of the research it was established that the majority of skills are developed in the process of managerial activity of managers. However the level achieved and speed of development of various skills differs.

The greatest changes occur in such managerial abilities as explanation of goals, conciseness and preciseness in setting objectives (65\% - with length of service under 3 years, $87 \%$ - with length of service over 10 years), thorough planning of the work process $(60 \%$ - with length of service under 3 years, $88 \%$ - with length of service over 10 years), time control (62 and 84\% respectively), and detail control (50 and 76\% respectively), delegation of authority (58 and $88 \%$ respectively), and manager's competence ( 54 and $86 \%$ respectively).

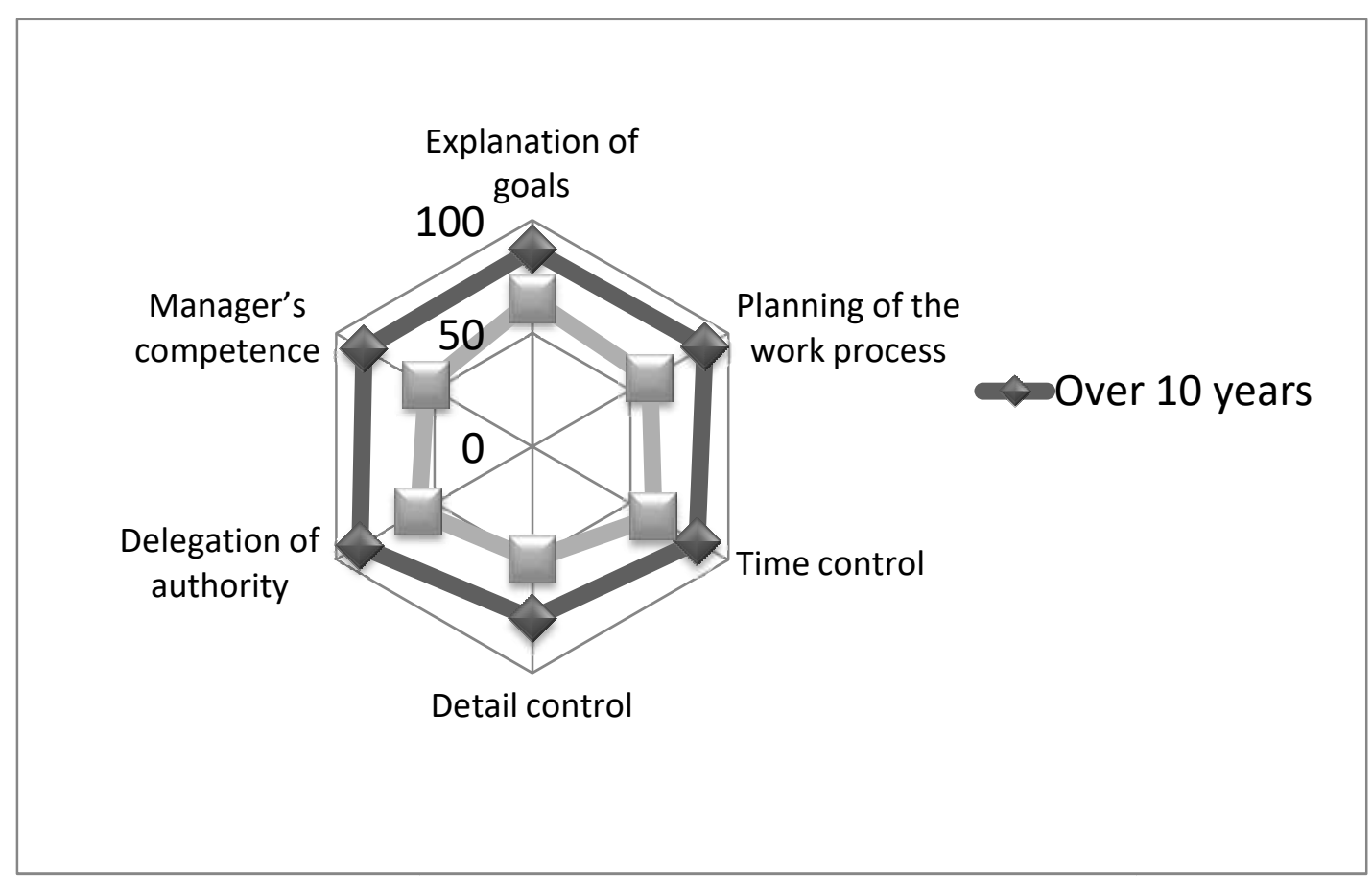

Fig.3. Cycle of managerial abilities

Experienced managers can control the work details without excessive pressure on employees and delegate authority to subordinates so that they could understand what is required of them and take responsibility for performance of the task. As the length of a manager's professional activity grows, the manager's qualities of prime importance are developed: organized nature, ability to foresee unfavourable circumstances; ability to run the work process so that the work to be implemented in the target dates. 
The following indicators that refer to organizing abilities also undergo sufficient changes: team building (67 and 78\% respectively), group cohesion (52 and 78\% respectively), and involvement in work activity (63 and $82 \%$ respectively).

Summarizing the above it should be emphasized that experienced managers with the length of management service over 10 years know the internal processes of the organization, policies and procedures, as well as incentive systemsbetter, and can determine the scope of their activity and that of the team's activity more clearly sharing their knowledge with subordinates.

In the course of professional managerial activity one develops the skills associated directly with the functions and competences of managers with abilities to manage the team efficiently, clearly explain the subordinates their goals and objectives and control the quality of the work performed.

Experienced managers have high level organizing abilities that are fulfilled in such significant organizing skills and competences of a manager as: team building, group cohesion, delegation of authority, and involvement in work activity.

All the above acmeological technologies including ASCAD, single system of tasks for teaching the methods of the project team building, training system and play-simulating were successfully tested in the system of continuous education of the North-Western Institute of management of the Russian Presidential Academy of National Economy and Public Administration to develop professional competence of project teams.

\section{REFERENCES}

Balasanyan A.S. Analizrazvitiyaprofessionalnoykompetentnostirukovoditeleyispetsialistov s ispolzovanieminformatsionnykhtekhnologiy[The analysis of development of professional competence of managers and specialists using information technologies]. Balasanyan A.S., Sofina V.N. [et.al.] VestnikKostromskogogosudarstvennogouniversitetaimeni N.A. Nekrasova, 2009-2010, V. 15, pp. 10-13.

1. Derkach A.A. Akmeologiya: lichnostnoeiprofessionalnoerazvitiecheloveka [Akmeology: personal and professional human development]. Akmeologicheskieosnovyupravlencheskoydeyatelnosti [Acmeological fundamentals of managerial activity]. Moscow, RAGS Publ., 2000. 536 p.

2. ObozovN.N. Intensivnayapodgotovkamenedzhera [Intensive training of a manger]. St. Petersburg, BKhV-PeterburgPubl., 2011. 240 p. 
3.

SofinaV.N.Akmeologicheskayakontseptsiyarazvitiyaprofessionalnoykompetentno $\begin{array}{lllll}\text { stistudentov } & v & \text { sistemeuchebno-nauchno } & - & \text { professionalnoyintegratsii }\end{array}$ [Acmeologicalconceptforthedevelopmentofprofessionalcompetenceofstudentsinasystemofaca demic-research-professionalintegration]. St. Petersburg, Sev.-Zap. in-t upr. - RANKhiGS Publ., 2015. 220 p.

4. SofinaV.N., GabovaM.P., BelyaevaA.A., VinokurovaO.Yu., GalchenkoA.S. Akmeologicheskiypodkhod $\mathrm{k}$ razvitiyuprofessionalnoykompetentnosti v proektnoydeyatelnosti s ispolzovanieminteraktivnykhtekhnologiy [Acmeological approach to the development of professional competence in project activity using interactive technologies].Vestnik LGU im. A.S. Pushkina, 2016, No. 4(1), p.205.

\section{How to cite this article:}

Polezhaeva O D, Galchenko A S, Sofina V N, Obozov N N, Gabova M P. System approach to development of professional competence of students and managers in project activity using acmeological technologies. J. Fundam. Appl. Sci., 2017, 9(2S), 1406-1415. 